\title{
Neuron-to-Glia Signaling Mediated by Excitatory Amino Acid Receptors Regulates ErbB Receptor Function in Astroglial Cells of the Neuroendocrine Brain
}

\author{
Barbara Dziedzic, ${ }^{\star}$ Vincent Prevot, ${ }^{\star}$ Alejandro Lomniczi, Heike Jung, Anda Cornea, and Sergio R. Ojeda \\ Division of Neuroscience, Oregon National Primate Research Center/Oregon Health \& Science University, Beaverton, Oregon 97006
}

Hypothalamic astroglial erbB tyrosine kinase receptors are required for the timely initiation of mammalian puberty. Ligand-dependent activation of these receptors sets in motion a glia-to-neuron signaling pathway that prompts the secretion of luteinizing hormonereleasing hormone (LHRH), the neuropeptide controlling sexual development, from hypothalamic neuroendocrine neurons. The neuronal systems that may regulate this growth factor-mediated back signaling to neuroendocrine neurons have not been identified. Here we demonstrate that hypothalamic astrocytes contain metabotropic receptors of the metabotropic glutamate receptor 5 subtype and the AMPA receptor subunits glutamate receptor 2 (GluR2) and GluR3. As in excitatory synapses, these receptors are in physical association with their respective interacting/clustering proteins Homer and PICK1. In addition, they are associated with erbB-1 and erbB-4 receptors. Concomitant activation of astroglial metabotropic and AMPA receptors results in the recruitment of erbB tyrosine kinase receptors and their respective ligands to the glial cell membrane, transactivation of erbB receptors via a mechanism requiring metalloproteinase activity, and increased erbB receptor gene expression. By facilitating erbB-dependent signaling and promoting erbB receptor gene expression in astrocytes, a neuron-to-glia glutamatergic pathway may represent a basic cell-cell communication mechanism used by the neuroendocrine brain to coordinate the facilitatory transsynaptic and astroglial input to LHRH neurons during sexual development.

Key words: glutamate receptors; astrocytes; growth factors; hypothalamus; neuron-glia signaling; erbB receptors; sexual development

\section{Introduction}

The initiation of mammalian puberty is determined by events that, taking place within the brain, result in an increased pulsatile secretion of luteinizing hormone-releasing hormone (LHRH), the neurohormone controlling sexual development (Plant, 1994; Terasawa, 1999). LHRH neurons, although intrinsically able to release LHRH episodically (Martínez de la Escalera et al., 1992), do not initiate the pubertal process themselves. Instead, their secretory activity increases at puberty in response to changing inputs from functionally connected neuronal and astroglial networks (Ojeda and Terasawa, 2002).

This dual neuronal-glial input provides the underpinnings for a set of regulatory processes collectively referred to as the "central drive" of puberty (Ojeda and Urbanski, 1994; Plant, 1994; Terasawa, 1999). The changes in central drive leading to the

\footnotetext{
Received July 1, 2002; revised 0ct. 29, 2002; accepted Nov. 11, 2002.

This work was supported by National Institutes of Health (NIH) Grant HD-25123 and National Institute of Child Health and Human Development/NIH through cooperative Grant U54 HD18185-16 as part of the Specialized Cooperative Centers Program in Reproduction Research and by Grant RR00163 for the operation of the Oregon Nationa Primate Center. B.D. was a visiting scientist supported by Grant TW05408 from the Fogarty International Center NIH. H.J. was a visiting scientist supported by a grant from the European Society for Pediatric Endocrinology. V.P. was a postdoctoral Research Fellow supported by a grant from Institut National de la Santé et de la Recherché Médicale (Paris, France).

${ }^{*}$ B.D. and V.P. contributed equally to this study.

Correspondence should be addressed to Sergio R. Ojeda, Division of Neuroscience, Oregon National Primate Research Center/Oregon Health \& Science University, 505 North West 185th Avenue, Beaverton, 0R 97006. E-mail: ojedas@ohsu.edu.

B. Dziedzic's present address: Department of Physiology, Medical University of Lodz, 91-130 Lodz, Poland.

H. Jung's present address: Eli Lilly and Company, D-61350 Bad Homburg, Germany.

V. Prevot's present address: Institut National de la Santé et de la Recherché Médicale U422, Place de Verdum, 59045 Lille Cedex, France.

Copyright $\odot 2003$ Society for Neuroscience $\quad 0270-6474 / 03 / 230915-12 \$ 15.00 / 0$
}

advent of sexual maturity appear to be determined by three major interrelated events, two of transsynaptic nature and one involving the activation of a glia-to-neuron communication pathway. A decrease in GABAergic inhibition (Terasawa, 1999 and an increase in glutamatergic stimulation of LHRH neurons (Ojeda and Urbanski, 1994; Bourguignon et al., 2000) currently are considered essential components of the transsynaptic mechanism controlling LHRH neurosecretion at puberty (Ojeda and Terasawa, 2002). Perhaps not surprisingly, growth factors required for early development of CNS neurons are emerging as sine qua non constituents of the back-signaling process used by astroglial cells to facilitate LHRH secretion during neuroendocrine sexual development (Ojeda et al., 2000).

Enhancement of glutamatergic neurotransmission, the primary mode of excitatory transsynaptic communication used by hypothalamic neurons (van den Pol and Trombley, 1993), increases LHRH secretion (Donoso et al., 1990; Claypool et al., 2000) and accelerates the initiation of puberty in both rats and monkeys (Urbanski and Ojeda, 1987; Plant et al., 1989; Urbanski and Ojeda, 1990). Glutamatergic neurons control LHRH secretion via at least two classes of ionotropic glutamate receptors: NMDA receptors, most of which are located on interneurons synaptically connected to LHRH neurons (Gore et al., 1996), and kainate receptors, which are expressed more abundantly on LHRH neurons themselves (Eyigor and Jennes, 1997, 2000).

Astroglial cells regulate LHRH secretion both by inducing plastic rearrangements within the median eminence and by activating specific glia-to-glia and glia-to-neuron signaling pathways (for review, see Ojeda et al., 2000). One of these pathways is set in motion by the epidermal growth factor-related peptides, trans- 
forming growth factor $\alpha$ (TGF $\alpha$ ) and neuregulins (NRGs). They elicit LHRH secretion indirectly (Ojeda et al., 2000) via a juxtacrine/paracrine mode of communication consisting of three steps: ligand-dependent activation of astroglial erbB-1 and erbB-4 receptors, release of bioactive substances (e.g., $\mathrm{PGE}_{2}$ ), and stimulation of LHRH secretion by a direct action of these substances on LHRH neurons (Ma et al., 1997, 1999; Rage et al., 1997). In hypothalamic astrocytes TGF $\alpha$ signals via erbB-1 (Ma et al., 1992) and NRGs via erbB-4 receptors (Ma et al., 1999). NRG binding to the latter results in the formation of heterodimeric erbB-4/erbB-2 complexes that initiate intracellular signaling (Ma et al., 1999). Pharmacological and genetic evidence now exists demonstrating that both erbB- 1 and erbB-4 receptors are required independently for normal sexual development. Thus either the blockade of median eminence erbB-1 receptor tyrosine kinase activity (Ma et al., 1992) or an inactivating point mutation of the erbB-1 gene (Apostolakis et al., 2000) delays the onset of female puberty in rodents. Similarly, female sexual development is delayed in mutant mice in which astroglial erbB-4 function is disrupted specifically by the targeted expression of a dominantnegative truncated form of the erbB-4 receptor (Prevot et al., 2003).

Although it follows that both glutamatergic neurotransmission and astroglial erbB-mediated back signaling are critical components of the neuroendocrine machinery controlling LHRH secretion during sexual development, nothing is known about the potential mechanisms that may be used by the neuroendocrine brain to relate these two regulatory pathways functionally. The structural and biochemical substrata required for such a relationship to operate are well established, because astrocytes are endowed with glutamate receptors (Blankenfeld and Kettenmann, 1991; Gallo and Ghiani, 2000) and respond to glutamate stimulation both with changes in immediate gene expression (Arenander et al., 1989; McNaughton and Hunt, 1992) and with the production of relevant bioactive molecules (Martin, 1992) such as $\mathrm{PGE}_{2}$ (Bezzi et al., 1998) and glutamate itself (Parpura et al., 1994; Bezzi et al., 1998). The present study demonstrates that the combined activation of ionotropic and metabotropic glutamate receptors (mGluRs) located on astroglial cells enhances the functional capability of astrocytic erbB signaling modules by favoring, within a short time frame, the establishment of productive ligand-erbB receptor interactions and inducing on a longer time basis an increase in erbB receptor gene expression.

\section{Materials and Methods}

\section{Cell culture}

Hypothalamic and cerebrocortical astrocytes cultures were prepared from 1- to 2-d-old Sprague Dawley rats as recommended by McCarthy and de Vellis (1980), with the modifications reported previously (Ma et al., 1994, 1999). After initial purification the astrocytes were plated in either six-well plates (at 400,000 cells per well) or in $15 \mathrm{~cm}$ dishes (at 1-1.5 million cells per dish). After reaching $90 \%$ confluence, the medium was replaced with an astrocyte-defined medium (ADM) (Ma et al., 1999), and the cells were used $48 \mathrm{hr}$ later for experiments.

\section{Treatments}

After $2 \mathrm{~d}$ in ADM the medium was replaced by fresh medium containing $100 \mu \mathrm{M}$ 1S,3R-ACPD (Research Biochemicals, Natick, MA), $100 \mu \mathrm{M}$ AMPA (Research Biochemicals), or $100 \mu \mathrm{M}$ 1S,3R-ACPD plus100 $\mu \mathrm{M}$ AMPA, and the cultures were continued for 2,4 , or $8 \mathrm{hr}$. At the end of each interval the cells were collected for RNA extraction. When immunohistochemistry was performed, the cells were fixed (see below) 5, 15, and $120 \mathrm{~min}$ after initiation of the treatment. For phosphorylation studies (see below) cellular proteins were collected from $15 \mathrm{~cm}$ dishes at 5 and 15 min after glutamate receptor stimulation.

\section{RNA extraction and RNase protection assay}

Total RNA was extracted using the procedure of Peppel and Baglioni (1990). The RNase protection assay that was used has been described previously in detail (Ma et al., 1996, 1999). The only difference was that, after completion of the hybridization, nonhybridizing species were digested by using $20 \mathrm{U}$ of RNase One (Promega, Madison, WI) instead of RNase A plus T1.

\section{Probes}

The antisense RNA probes used to detect metabotropic and AMPA receptor mRNAs in RNase protection assays were prepared with DNA templates corresponding to sequences contained in the coding region of each mRNA. The original cDNAs encoding the entire coding regions of the metabotropic receptors mGluR1 to mGluR6 were generously provided by Dr. S. Nakanishi (Institute for Immunology, Kyoto University, Kyoto, Japan). The cDNAs encoding the AMPA receptor subunits GluR1, GluR2, GluR3, and GluR4 were the generous gift of Dr. J. Boulter (University of California, Los Angeles, CA).

\section{Metabotropic receptors}

Metabotropic glutamate receptor 1. A 499 base BglII/SphI fragment, corresponding to nucleotides (nt) 2433-2932 in the intracellular-encoding region of mGluR1 cDNA (Masu et al., 1991), was subcloned into the plasmid pSP72 (Promega). Antisense transcripts were prepared by transcription of the template with SP6 RNA polymerase after linearization with AccI.

Metabotropic glutamate receptor 2. The mGluR2 DNA template was obtained by cloning a $296 \mathrm{bp} \mathrm{NcoI} \mathrm{fragment,} \mathrm{corresponding} \mathrm{to} \mathrm{nt} \mathrm{1351-}$ 1647 in the extracellular domain-encoding portion of rat mGluR2 mRNA (Tanabe et al., 1992), into the NcoI site of pGEM-5zf. After linearization with $S t u I$ a $c R N A$ probe was prepared by transcription with SP6 RNA polymerase.

Metabotropic glutamate receptor 3. An mGluR3 cDNA template was prepared by cloning into pSP72 a SphI/SmaI 362 bp fragment, corresponding to nt 1348-1710 in the extracellular domain-encoding portion of rat mGluR3 mRNA (Tanabe et al., 1992). Antisense transcripts were generated by transcription with T7 RNA polymerase after linearization of the template with HindIII.

Metabotropic glutamate receptors 4, 5, and 6. The required cDNA templates were prepared by subcloning a HindIII/KpnI 285 bp fragment (nt $1428-1713$ in the extracellular domain-encoding portion of rat mGluR4 mRNA) (Tanabe et al., 1992) into pGEM-3Z, a Ball 403 bp fragment (nt 727-1129 in the extracellular domain-encoding portion of rat mGluR5 mRNA) (Abe et al., 1992) into the SmaI site of pGEM-3Z, and a PvuII/ Pst 305 bp fragment (nt 2269-2574 in the transmembrane-intracellular domain-encoding portion of rat mGluR6 mRNA) (Nakajima et al., 1993) into pSP72. After linearization with HindIII, EcoRI, or XbaI the corresponding mGluR4, 5 , and 6 cRNAs were prepared by transcription with T7 (mGluR4) or SP6 (mGluR5 and 6) RNA polymerases.

\section{AMPA receptors}

Glutamate receptors 1,2 , and 3 . The cDNA templates were generated by cloning a $P v u I I 220$ bp fragment (nt 956-1179 in rat GluR1 mRNA) (Hollmann et al., 1989), a KpnI/ApaI 342 bp fragment (nt 1014-1356 in rat GluR2 mRNA) (Boulter et al., 1990), and an EcoRI 279 bp fragment (nt 749-1028 in rat GluR3 mRNA) (Boulter et al., 1990) into the riboprobe vectors pSP72 (GluR1) and pBluescript SK ${ }^{+/-}$(GluR2 and 3). Antisense GluR1 transcripts were generated by transcribing a XhoIlinearized plasmid with T7 RNA polymerase. The GluR2 and GluR3 cRNA probes were prepared by T3-mediated transcription of KpnI and HindIII-linearized plasmids, respectively.

Glutamate receptor 4 . A cDNA template was prepared by first removing a XbaI $2548 \mathrm{bp}$ fragment from the original pK46 plasmid containing a full-length GluR4 cDNA (Boulter et al., 1990), followed by religation of the remaining plasmid. A shorter antisense probe (206 bp) corresponding to nt 217-423 in rat GluR4 mRNA was generated by linearizing the cDNA template with $\mathrm{NcoI}$, followed by T3 RNA polymerase-mediated transcription. 

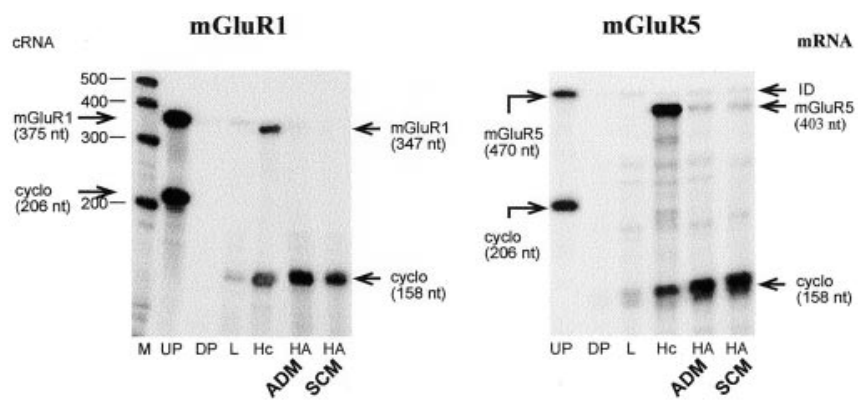

Figure 1. Detection of Group I (mGluR1 and mGluR5) metabotropic glutamate receptor mRNAs in hypothalamic astrocytes $(H A)$ cultured in astrocyte-defined medium (ADM) or serum-containing medium $(S C M)$, as assessed by RNase protection assay. Note that only mGluR5 mRNA is expressed in these cells. $M$, RNA molecular markers; UP, undigested probe; DP, digested probe; cyclo, cyclophilin mRNA; $L$, liver; $H c$, hippocampus; $I D$, incomplete digestion.

\section{ErbB receptors}

ErbB-1. To generate a probe recognizing the $5^{\prime} \mathrm{mRNA}$ sequence common to the full-length and truncated forms of erbB-1 (Petch et al., 1990), we excised a $199 \mathrm{bp}$ fragment from a cDNA template described previously (Junier et al., 1993), using an internal erbB-1 NsiI site and a SpeI site in the multiple cloning site of pBluescript SK. After religation and linearization with $\mathrm{XbaI}$, an erbB-1 antisense probe protecting $256 \mathrm{bp}$ of erbB-1 mRNA was transcribed with T7 RNA polymerase.

ErbB-2 and erbB-4. The cRNA probes used to detect erbB-2 and erbB-4 mRNAs were those described previously (Ma et al., 1999).

\section{Reverse transcription-PCR}

DNA fragments derived from the coding region of the mRNAs encoding the metabotropic receptor-clustering protein Homer 1a (Brakeman et al., 1997) and the AMPA receptor-interacting/clustering proteins GRIP (glutamate receptor-interacting protein) (Dong et al., 1997), PICK1 (protein interacting with C-kinase) (Xia et al., 1999), and NSF ( $N$ ethylmaleimide-sensitive fusion protein) (Nishimune et al., 1998; Song et al., 1998) were generated by reverse transcription (RT)-PCR of total RNA extracted from rat hypothalamic astrocytes, hippocampus, and liver. Then $200 \mathrm{ng}$ of RNA was transcribed into cDNA in a final volume of

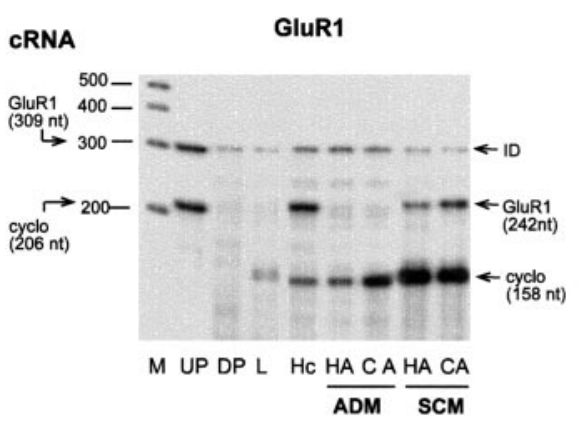

GluR3

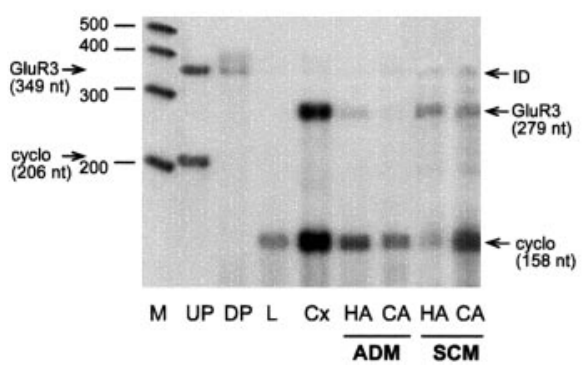

Figure 2. Detection of AMPA receptor subunits (GluR1-GluR4) in hypothalamic astrocytes $(H A)$ and cerebrocortical astrocytes ( $C A$ ) cultured in ADM or SCM. Note that only GluR2 mRNA is expressed in both ADM and SCM. Cx, Cerebral cortex. For other abbreviations, see legend to Figure 1.
$20 \mu \mathrm{l}$ containing $200 \mathrm{U}$ of Maloney murine leukemia virus reverse transcriptase (Life Technologies, Grand Island, NY), 20 U of RNase inhibitor (Promega), and $25 \mathrm{pmol}$ of oligo-dT primer. After a $2 \mathrm{hr}$ incubation at $37^{\circ} \mathrm{C}$ the reaction was stopped by heating at $95^{\circ} \mathrm{C}$ for $5 \mathrm{~min}$.

PCRs were performed by using $2 \mu \mathrm{l}$ of each reverse transcription reaction and Taq DNA polymerase (Promega) in a volume of 25-60 $\mu$ l. The thermocycling conditions for Homer 1a, NSF, and PICK1 were $95^{\circ} \mathrm{C}$ for $4 \mathrm{~min}$, followed by 36 cycles of $94^{\circ} \mathrm{C}$ for $15 \mathrm{sec}, 55^{\circ} \mathrm{C}$ for $1 \mathrm{~min}$, and $72^{\circ} \mathrm{C}$ for $2 \mathrm{~min}$, followed by a final extension period of $7 \mathrm{~min}$ at $72^{\circ} \mathrm{C}$. The thermocycling conditions for GRIP were those recommended for touchdown PCR (Hecker and Roux, 1996)

Homer 1a. A 270 bp DNA fragment was amplified with 20-mer oligodeoxynucleotide primers (sense, $5^{\prime}$-TCTTCAGCACTCGAGCTCAT$3^{\prime}$, and antisense, 5'-GATGATGCTCAGAGGAGAAT-3') corresponding to nt 583-602 and 833-851, respectively, in the open reading frame of Homer la mRNA (Brakeman et al., 1997).

GRIP, glutamate receptor-interacting protein. A 267 bp DNA fragment complementary to nt 3189-3455 in rat GRIP mRNA (Dong et al., 1997) was amplified by using 20-mer primers (sense, 5' -TTCAGTGTGGC-

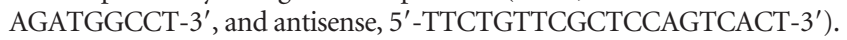

PICK1, protein interacting with C-kinase. A 246 bp PICK1 DNA fragment corresponding to nt 812-1058 in the murine PICK1 mRNA sequence (Staudinger et al., 1995) was amplified by using 21-mer primers (sense, 5' -ATGACGAGGAATACAGCTGCA-3', and antisense, 5'-GCAGCACTGCATAGCAGTCA-3'.

NSF, $N$-ethylmaleimide-sensitive fusion protein. To amplify a $281 \mathrm{bp}$ fragment of NSF mRNA, we used 21-mer primers (sense, 5'-TCGACGCCATCTGCAAGCAGA-3', and antisense, 5' -ATCCGCAGACAGTAGCTGGTG-3') corresponding to nt 993-1013 and 1253-1273, respectively, in the coding region of NSF (GenBank accession number AF142097).

All cDNAs generated by RT-PCR were cloned into the riboprobe vector pGEM-T (Promega), and their identities were verified by sequencing.

\section{Antibodies, growth factors, and inhibitors}

The sheep polyclonal antibody used for the immunoprecipitation of erbB-1 was obtained from Fitzgerald Industries (Concord, MA). The rabbit polyclonal antibody used for the immunoprecipitation of erbB-4 (Ab-1) was obtained from NeoMarkers (Fremont, CA). Polyclonal antibodies used for the immunoprecipitation of Homer (sc-8921) and the Western blot detection of erbB-1 (sc-03-G) and erbB-4 (sc-283) were purchased from mRNA Santa Cruz Biotechnology (Santa Cruz, CA). The rabbit polyclonal antibodies used for the Western blot detection of GluR2/3 and mGluR5 were obtained from Upstate Biotechnology (Lake Placid, NY). The monoclonal antibody used for the detection of phospho-Tyr (4G10) levels and the rabbit polyclonal antibody against PICK1 were a generous gift from Drs. Brian Druker (Oregon Health \& Science University, Portland, OR) and R. Huganir (Johns Hopkins University, Baltimore, MD), respectively. The secondary antibodies, antimouse and anti-rabbit peroxidase conjugate (HRP), were from Pierce (Rockford, IL), and the anti-goat/sheep HRP (GT-34) was obtained from Sigma (St. Louis, MO). Betacellulin was from R\&D Systems (Minneapolis, $\mathrm{MN}$ ), and the metalloproteinase inhibitor GM6001 (Ilomastat) was from Chemicon (Temecula, CA).

\section{Immunoprecipitation}

After treatment the cells were rinsed once with ice-cold PBS and snap-frozen on dry ice. Cell lysates were prepared in $25 \mathrm{~mm}$ Tris, $\mathrm{pH} 7.4$, containing (in mM) $50 \beta$-glycerophosphate, 1.5 EGTA, 0.5 EDTA, 1 sodium pyrophosphate, and 1 sodium orthovanadate plus (in 
$\mu \mathrm{g} / \mathrm{ml}) 10$ leupeptin and pepstatin, 10 aprotinin, 100 PMSF, and 1\% Triton X-100. Cell lysates were normalized according to protein concentration with the BSA kit (Bio-Rad; Hercules, CA). For immunoprecipitation of erbB receptors, Homer and PICK1, equal amounts of protein $(0.8-1 \mathrm{mg})$ contained in a total volume of $750 \mu \mathrm{l}$ of lysis buffer were incubated with $2 \mu \mathrm{g}$ of the respective antibody with gentle rocking for $1.5 \mathrm{hr}$ at $4^{\circ} \mathrm{C}$. Thereafter, $60 \mu \mathrm{l}$ of protein A-Sepharose (Sigma) was added, and the reaction was allowed to proceed for $45 \mathrm{~min}$. The Sepharose beads were washed twice with icecold lysis buffer and boiled in $50 \mu$ of sample buffer containing $187 \mathrm{~mm}$ Tris-base, 9\% SDS, $15 \%$ glycerol, and $15 \% \beta$-mercaptoethanol, $\mathrm{pH}$ 6.8. When it was necessary, the samples were stored at $-85^{\circ} \mathrm{C}$ until use.

\section{Western blotting}

Samples were boiled again after thawing and electrophoresed for $2 \mathrm{hr}$ at $130 \mathrm{~V}$ in $4-20 \%$ precast SDS-polyacrylamide gels (Gradipore, Frenchs Forest, Australia). After fractionation the proteins were transferred onto polyvinylidene difluoride membranes (Pierce) for $3 \mathrm{hr}$ at $4^{\circ} \mathrm{C}$. Blots were blocked for $1 \mathrm{hr}$ in $2.5 \%$ EIA grade gelatin (Bio-Rad, Hercules, CA) in Tris-

buffered saline (TBS) at $37^{\circ} \mathrm{C}$ for phosphotyrosine detection, in SuperBlock blocking buffer (Pierce) for erbB receptors detection, or in Tween/ TBS (TBST) 3\% nonfat milk at room temperature for the detection of PICK1, Homer, GluR2/3, and mGluR5. Then the blots were reacted overnight with their respective primary antibody and washed in TBST before being exposed for $1 \mathrm{hr}$ to HRP-conjugated secondary antibodies. The immunoreactions were detected with Renaissance chemiluminescence reagents (NEN Life Sciences, Boston, MA).

\section{Immunohistofluorescence-confocal microscopy}

The cultures were washed twice with PBS, $\mathrm{pH} 7.4$, and fixed in $4 \%$ paraformaldehyde for $30 \mathrm{~min}$ at room temperature. After extensive washes in $0.02 \mathrm{M}$ potassium phosphate buffer containing $0.9 \% \mathrm{NaCl}$ (KPBS), the cells were incubated for $15 \mathrm{~min}$ in KPBS-A ( $0.02 \mathrm{M}$ KPBS containing $0.4 \%$ Triton X-100), followed by $15 \mathrm{~min}$ in avidin blocking solution (avidin/ biotin blocking kit, Vector Laboratories, Burlingame, CA) and 15 min in biotin blocking solution. After three washes in LKPBS (KPBS containing $0.3 \%$ heat-inactivated goat serum and $0.1 \%$ Triton $\mathrm{X}-100)$ the cultures were incubated for $48 \mathrm{hr}$ at $4^{\circ} \mathrm{C}$ with the primary antibodies diluted in the same buffer.

Depending on the antibodies used to visualize glutamate receptors or members of the erbB signaling module (see below), astrocytes were labeled with either a monoclonal antibody to glial fibrillary acidic protein (GFAP; 1:20,000; Sigma) or anti-GFAP polyclonal antibodies (1:100; Dako, Carpinteria, CA). The GFAP immunoreactions were developed either with Texas Red-conjugated goat anti-mouse IgGs (1:250; Jackson ImmunoResearch Laboratories, West Grove, PA) when the GFAP antibody was monoclonal or with Texas Red-conjugated goat anti-rabbit IgGs (1:250, Jackson ImmunoResearch Laboratories) when the GFAP antibodies were polyclonal. The metabotropic receptor mGluR5 and the AMPA receptors Glu2 and Glu3 were detected with rabbit polyclonal antibodies to mGluR5 (Upstate Biotechnology, Lake Placid, NY) or to GluR2/3 (Chemicon International, Temecula, CA), both at a 1:1000 dilution. ErbB-1 receptors were detected with sheep antiserum epidermal growth factor (EGF-R; Fitzgerald Industries) diluted 1:200 and erbB-4 with monoclonal antibody c-erbB-4, Ab-1 (NeoMarkers), at a 1:100 dilution. TGF $\alpha$ was detected with rabbit polyclonal antibodies RGG-8040 (diluted 1:200; Peninsula Laboratories, San Carlos, CA). The appropriate biotinylated goat anti-rabbit and goat anti-mouse IgGs (diluted 1:200) were used to develop the immunohistochemical reactions of GluR2/3, mGluR5, or erbB-4 receptors with their respective primary antibodies. After several washes with KPBS the cultures were incubated with fluores- cein (FITC)-conjugated streptavidin (1:400; Jackson ImmunoResearch Laboratories) for $1 \mathrm{hr}$ at room temperature. The secondary antibodies used to visualize TGF $\alpha$ and erbB-1 were an FITC-conjugated donkey anti-rabbit immunoglobulin (Vector Laboratories) diluted 1:600 to detect TGF $\alpha$ and a biotinylated donkey anti-sheep IgG (1:600; Vector Laboratories), followed by Texas Red-labeled streptavidin (1:600; Amersham Biosciences, Piscataway, NJ) to detect erbB-1. Control sections were incubated in the absence of primary antibodies.

Confocal images were acquired and processed as described previously (Ma et al., 1999; Dissen et al., 2001), using a Leica (Nussloch, Germany) TCS SP confocal system with a $40 \times$ Plan Apochromat objective and a 1.25 numerical aperture.

\section{Results}

Hypothalamic astrocytes express the glutamate metabotropic receptor mGluR5 and the AMPA receptor GluR2 and GluR3 subunits

To determine whether metabotropic and AMPA receptor subunits are expressed in hypothalamic astrocytes, we subjected total RNA from astrocyte cultures maintained in either ADM or serum-containing medium (SCM) to an RNase protection assay. As observed previously in astrocytes of other brain regions (Martin et al., 1992; Condorelli et al., 1997), no mGluR1 mRNA was detected in hypothalamic astrocytes cultured in ADM or SCM (Fig. 1). In contrast, and in agreement with previous reports demonstrating the presence of mGluR 5 mRNA in hypothalamic astrocytes in situ (van den Pol et al., 1995) and cortical astrocytes in culture (Miller et al., 1995; Balázs et al., 1997; Nakahara et al., 1997), mGluR5 mRNA was expressed in astrocytes grown in either ADM or SCM (Fig. 1). No evidence for the expression of mGluR2, mGluR3, mGluR4, or mGluR6 mRNAs in either hypothalamic or cerebrocortical astrocytes cultured in ADM or SCM was found, with the possible exception of low levels of mGluR3 mRNA in astrocytes maintained in SCM (data not shown). Previous studies have reported the presence of mGluR3 in astrocytes in situ (Testa et al., 1994) and in vitro (Petralia et al., 1996; Bruno et al., 1997).

The most abundant AMPA receptor subunit mRNA expressed in hypothalamic astrocytes was GluR2 mRNA, which was 

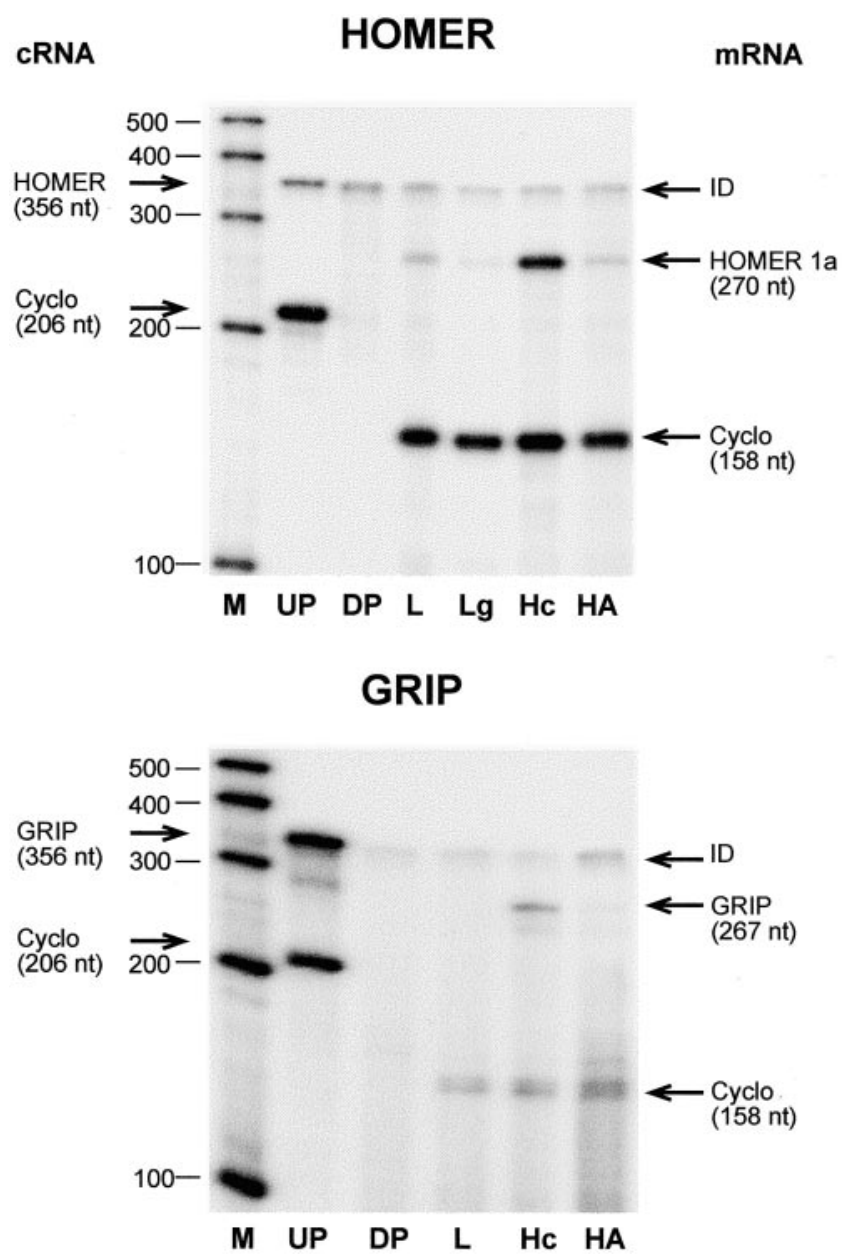

Figure 4. Detection of the mRNA encoding the mGluR1/R5 metabotropic receptorinteracting protein Homer $1 \mathrm{la}$ (top) and trace amounts of the AMPA receptor-clustering protein GRIP (bottom) in hypothalamic astrocytes cultured in ADM. Lg, Lung. For other abbreviations, see legend to Figure 1.

present in cultures maintained in either ADM or SCM (Fig. 2). GluR2 mRNA appeared to be equally abundant in hypothalamic and cerebrocortical astrocytes, with levels of expression decreasing when the cells were cultured in the absence of serum. The presence of serum appears to be necessary for the expression of GluR1 and GluR3 mRNAs, because they were not detected in astrocytes cultured in ADM but were clearly present in astrocytes grown in SCM (Fig. 2). In contrast, only traces of GluR4 mRNA were detected in hypothalamic and cortical astrocytes cultured in either ADM or SCM (Fig. 2). Thus mGluR5 and GluR2 are the glutamate receptors most predominantly expressed in hypothalamic astrocytes.

Immunohistofluorescence-confocal microscopy studies that used antibodies against mGluR5 or GluR2/3 demonstrated that both proteins are indeed present in these cells (Fig. 3). In both cases the immunoreactivity was punctuated and appeared unevenly distributed, with dense areas adjacent to areas relatively free of immunoreactive material.

Hypothalamic astrocytes express the genes encoding metabotropic and AMPA glutamate receptor anchoring/interacting proteins

To determine whether hypothalamic astrocytes express the mRNAs encoding Homer 1a, a metabotropic receptor-cluster- ing/scaffold protein that binds mGluR1 and mGluR5 (Brakeman et al., 1997), and the AMPA receptor-interacting/clustering proteins GRIP (Dong et al., 1997), NSF (Nishimune et al., 1998; Song et al., 1998), and PICK1 (Xia et al., 1999), we subjected total RNA from hypothalamic astrocytes to RT-PCR amplification with oligodeoxynucleotide primers intended to amplify DNA segments contained in the coding region of Homer 1a, GRIP, NSF, and PICK1 mRNAs. After identification of the PCR products by sequencing, the DNA fragments were used as templates to prepare cRNA probes for RNase protection assay. Using this assay, we detected in hypothalamic astrocytes the mRNAs encoding Homer 1a, GRIP, NSF, and PICK1 (Figs. 4, 5). Overall, GRIP mRNA was the least abundant and PICK1 the most abundant. The astrocytic content of Homer la was similar to that of liver and lung, two peripheral tissues shown to express this protein (Brakeman et al., 1997), and lower than in the hippocampus (Fig. $4, t o p)$, a region of the brain in which Homer 1a is expressed more abundantly under resting conditions (Brakeman et al., 1997; Xiao et al., 1998). The content of GRIP mRNA, which encodes a nonclustering protein (Xia et al., 1999) that associates with both GluR2 and GluR3 AMPA receptor subunits (Dong et al., 1997), was much lower in astrocytes than in hippocampal tissue (Fig. 4, bottom). Consistent with its preferential expression in the CNS

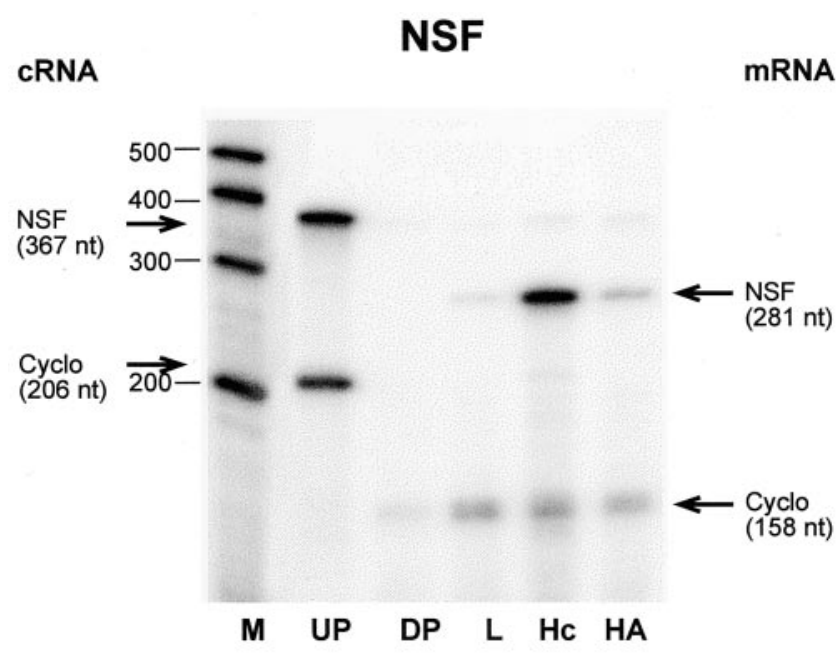

\section{PICK1}

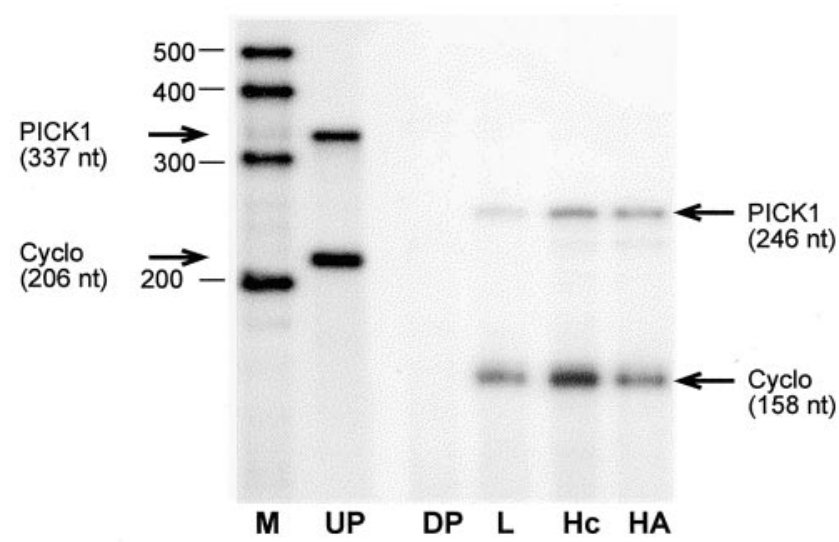

Figure 5. Detection of the mRNAs encoding the AMPA receptor-clustering proteins NSF (top) and PICK1 (bottom) in hypothalamic astrocytes cultured in ADM. For abbreviations, see legend to Figure 1. 
(Püschel et al., 1994), NSF mRNA was more abundant in hypothalamic astrocytes than in liver, a peripheral tissue also expressing the NSF gene (Püschel et al., 1994), but clearly less than in the hippocampus (Fig. 5, top). In contrast, PICK1 mRNA encoding a synaptic protein that preferentially colocalizes with GluR2 in excitatory synapses and induces clustering of AMPA receptors (Xia et al., 1999) was as abundant in hypothalamic astrocytes as in the hippocampus (Fig. 5, bottom).

\section{Homer/mGluR5 and PICK1/GluR2/3 are associated physically in hypothalamic astrocytes}

To determine whether the Homer and PICK1 proteins actually are expressed in hypothalamic astrocytes and are able to interact with mGluR5 and GluR2/3 as they do in neurons, we performed immunoblots and coimmunoprecipitation assays. Both receptors and their interacting proteins were detected readily in Western blots (Fig. $6 A / D$ and $B / E$, respectively). Consistent with the results of RNase protection assays, hypothalamic astrocytes contain higher levels of PICK1 (Fig. 6E) than Homer 1a protein (Fig. $6 B$ ). In turn, Homer 1a is expressed at lower levels than other members of the Homer family (Homer $1 \mathrm{~b} / \mathrm{c}$ ) detected by the antibody that was used, which recognizes the common $\mathrm{N}$ terminus of all Homer 1 isoforms. This expression profile is in agreement with that observed in the normal brain, in which basal noninduced Homer la levels are considerably lower than those of the other, constitutively expressed, family members (Xiao et al., 1998). Immunoprecipitation with Homer antibodies resulted in the coprecipitation of mGluR5 (Fig. 6C), and the immunoprecipitation of PICK1 coprecipitated GluR2/3 (Fig. 6F). Thus hypothalamic astrocytes contain the same metabotropic/AMPA glutamatergic receptor-interacting cellular protein complexes that neurons use for synaptic communication.

\section{Coactivation of metabotropic and AMPA/kainate receptors induces cellular redistribution of erbB receptors in hypothalamic astrocytes}

Coactivation of AMPA and mGluRs results in astrocytic $\mathrm{PGE}_{2}$ release via a mechanism that is not set in motion by the activation of each receptor class alone (Bezzi et al., 1998). To determine whether AMPA and metabotropic receptors are able to affect erbB receptor physiology individually or require a similar interaction, we exposed hypothalamic astrocytes cultured in ADM to either AMPA or tACPD alone or to a combination of both agonists. Immunohistofluorescence-confocal microscopy examination of the treated cells showed that under unstimulated conditions a significant fraction of the erbB-4 receptors had a perinuclear localization (Fig. 7A,A1; examples denoted by arrowheads) suggestive of an association of the protein with the Golgi apparatus. Although activation of metabotropic receptors alone with tACPD somewhat changed this localization (Fig. 7B, B1; examples denoted by arrows), treatment with AMPA (Fig. 7C,C1) and, particularly, coactivation of metabotropic and AMPA/kai-
B

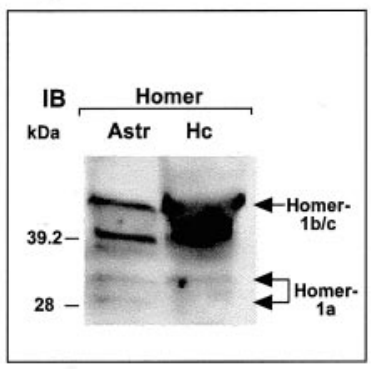

E

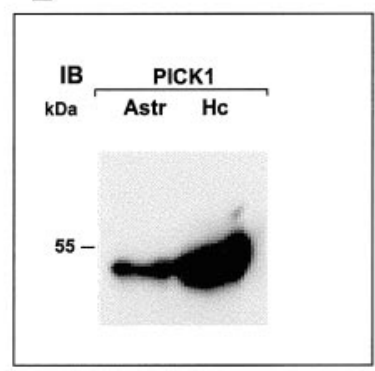

C

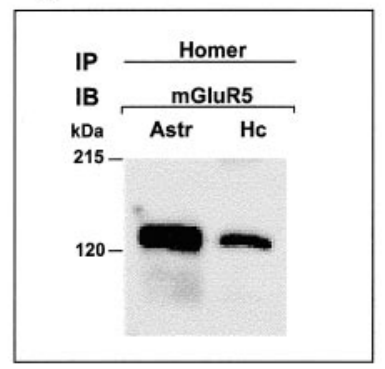

F

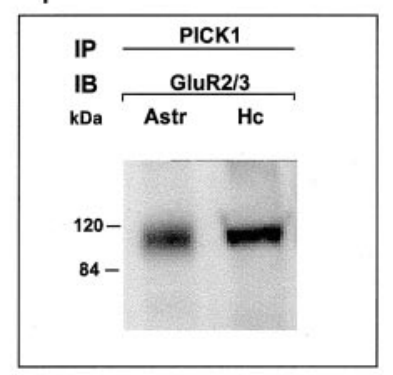

Figure 6. Hypothalamic astrocytes contain mGluR5 receptors $(A)$, the AMPA receptor subunits GluR2/3 (D), and their respec-

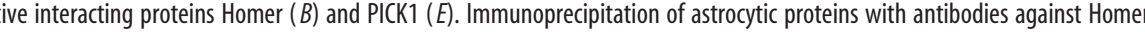
results in the coprecipitation of mGluR5 ( $C$, and the immunoprecipitation of PICK1 coprecipitates GluR2/3 ( $F$ ). Astr, Astrocytes; $H C$

nate receptors (Fig. 7D,D1) resulted in redistribution of erbB-4 receptor immunoreactive material to the cell membrane (examples denoted by arrows). Similar changes were observed in the case of erbB-1 receptors (data not shown).

Coactivation of metabotropic and AMPA/kainate receptors induces physical approximation of erbB receptors and their respective ligands on the cell membrane of astrocytes

Under basal unstimulated conditions a substantial fraction of TGF $\alpha$ and its erbB-1 receptor appeared to have a perinuclear and cytoplasmic localization (Fig. 8, top panels). Little, if any, immunoreactivity was associated with the cell membrane (Fig. 8, arrowheads) visualized by differential interference contrast (DIC) (Fig. 8, bottom panels, arrowheads). Within $15 \mathrm{~min}$ of simultaneously exposing the astrocytes to ACPD and AMPA, we could visualize both TGF $\alpha$ and erbB-1 immunoreactive material in apparent association with cell membranes (Fig. 8, middle panels, examples denoted by arrows; DIC image shown in bottom panels). Overlapping of both immunoreactivities was also evident (Fig. 8, right middle panel), suggesting a close proximity of the TGF $\alpha$ ligand to its erbB receptor. Similar changes were observed in the case of NRG- $\beta$ and its erbB-4 receptor (data not shown).

Both TGF $\alpha$ and its receptor erbB-1 also were seen in the cell nucleus of both unstimulated and treated cells, in agreement with recent observations showing the nuclear localization of both proteins (Lin et al., 2001; Grasl-Kraupp et al., 2002), where they may function as transcription factors (Lin et al., 2001).

\section{Coactivation of metabotropic and AMPA/kainate receptors leads to a metalloproteinase-dependent activation of astrocytic erbB receptors}

To determine whether the apparent ligand/erbB receptor approximation induced by AMPA/tACPD treatment leads to a productive interaction, we examined treated and untreated astro- 

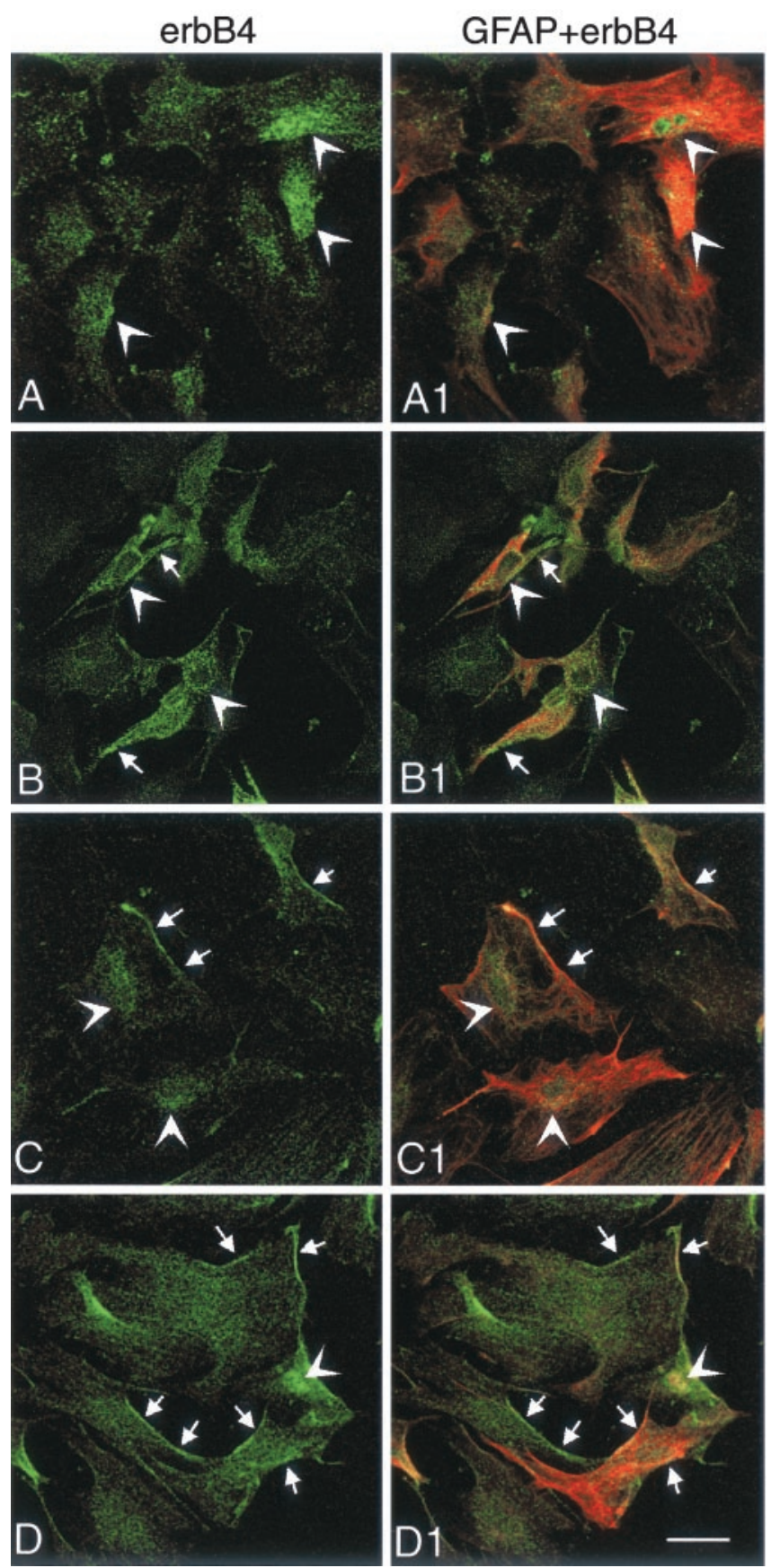

Figure 7. Coactivation of metabotropic and AMPA receptors induces cellular redistribution of erbB-4 receptors in hypothalamic astrocytes as assessed by immunohistofluorescence- confocal microscopy. Under basal unstimulated conditions a substantial fraction of the erbB-4 immunoreactive material has a perinuclear localization $(A, A 1$; examples denoted by arrowheads). Treatment with $A C P D$ to activate metabotropic receptors partially changes this localization ( $B, B 1$; examples of redistribution denoted by arrows), but AMPA $(C, C 1)$ and especially tACPD plus AMPA $(D, D 1)$ induce redistribution of the immunoreactivity to the cell membrane (denoted by arrows). Scale bar, $40 \mu \mathrm{m}$.

cytes for erbB receptor phosphorylation. Within 5-15 min of exposure to tACPD/AMPA there was tyrosine phosphorylation of both erbB-1 and erbB-4 receptors (Fig. 9A), indicating that the physical approximation between TGF $\alpha$ and NRG and their respective receptors suggested by confocal microscopy indeed results in receptor activation. As expected, exposure of the cultures to betacellulin, an EGF family member that binds and activates both erbB-1 and erbB-4 homodimers and all possible het- erodimeric erbB receptor complexes (Dunbar and Goddard, 2000 ), resulted in strong phosphorylation of both erbB-1 and erbB-4 receptors (Fig. 9A).

Transactivation of erbB- 1 receptors induced by activation of G-protein-coupled receptors has been shown to involve cleavage of membrane-bound erbB ligands by metalloproteinases (Prenzel et al., 1999). Moreover, TACE [tumor necrosis factor- $\alpha$ converting enzyme; ADAM-17 (a disintegrin and metalloproteinase)], a member of the ADAM family of metalloproteinases, has been shown to be essential for the release of the mature TGF $\alpha$ peptide from its membrane-anchored precursor (Peschon et al., 1998). It then follows that that regulation of ligand availability by metalloproteinase-dependent mechanisms may be an integral component of the process by which erbB receptors are activated by their ligands. To determine whether this mechanism contributes to the process by which glutamate receptors induce astrocytic erbB receptor phosphorylation, we treated hypothalamic astrocytes with GM6001, a broad spectrum inhibitor of metalloproteinase activity, for $30 \mathrm{~min}$ before exposing them to tACPD/ AMPA. As shown in Figure 9, inhibition of metalloproteinase activity obliterated the ability of these glutamate receptor agonists to induce both erbB-1 and erbB-4 receptor phosphorylation. Thus cleavage of erbB receptor ligands followed by binding to their respective receptors is likely to underlie the activation of erbB receptor signaling induced by glutamate on hypothalamic astrocytes.

The functional relationship between AMPA/metabotropic receptors and astrocytic erbB receptors shown by the aforementioned studies may reflect the existence of a physical association between these receptors. To examine this possibility, we performed coimmunoprecipitation assays and found that immunoprecipitation of either erbB- 1 or erbB- 4 results in the coprecipitation of GluR2/3 and mGluR5 (Fig. 9B). Similar assays performed to determine whether erbB-1 and/or erbB-4 is/are in complex with either Homer or PICK1 resulted in a low level of coprecipitation (data not shown), suggesting the absence of a direct interaction between these proteins.

\section{Coactivation of metabotropic and AMPA/kainate receptors} induces erbB receptor expression in hypothalamic astrocytes Treatment of hypothalamic astrocytes for 2-8 hr with either tACPD or AMPA (at $100 \mu \mathrm{M}$ each) to activate selectively the metabotropic or AMPA/kainate receptors did not affect the steady-state levels of the mRNAs encoding erbB-1, erbB-2, or erbB-4, the three members of the erbB family of tyrosine kinase receptors expressed in these cells (Ma et al., 1999) (Fig. 10). In contrast, coactivation of AMPA/kainate metabotropic receptors significantly $(p<0.05)$ increased erbB- 1 and erbB-2 mRNA levels within $4 \mathrm{hr}$ of treatment (Fig. 10), with the effect persisting after $8 \mathrm{hr}(p<0.01)$. Unexpectedly, the erbB-4 gene did not respond like its congeners, because erbB- 4 mRNA content remained unchanged throughout the duration of the treatment (Fig. 10).

\section{Discussion}

The present results indicate that costimulation of metabotropic and AMPA receptors on hypothalamic astrocytes leads to transactivation of erbB-1 and erbB-4 receptor signaling in these cells. The cellular underpinnings of this activation include recruitment of the erbB receptors to the cell membrane, physical approximation of the receptors to their respective membrane-bound TGF $\alpha$ and NRG ligands (also located on astrocytes), and the phosphorylation of each erbB receptor by a mechanism that appears to 
require processing of erbB ligand precursors by extracellular proteases of the matrix metalloproteinase family. By revealing the involvement of glutamate receptors in a neuron-to-glia communication pathway able to activate erbB receptor signaling in hypothalamic astrocytes, these results implicate this pathway as a mechanism that the neuroendocrine brain may use to coordinate the activation of glutamatergic neurons and astroglial cells during sexual development.

The increase in LHRH secretion required for the initiation of the pubertal process appears to be determined by a coordinated decrease in transsynaptic GABA inhibition of LHRH neuronal function (Terasawa, 1999), an increase in glutamatergic inputs to these and other synaptically connected neuronal networks (Bourguignon et al., 2000; Ojeda et al., 2001), and the activation of a glia-toneuron signaling pathway mediated by erbB receptors and their ligands operating in astrocytes of the neuroendocrine brain (Ojeda et al., 2000) (for review, see Ojeda and Terasawa, 2002). Although each of these regulatory mechanisms has been characterized individually, the cell-cell mechanisms responsible for the coordination of neuron-to-neuron and neuron-toglia inputs to the LHRH neuronal network have not been identified. Emerging evidence suggests that in other regions of the brain GABAergic neurons are controlled by glutamatergic neurons, which use AMPA and kainate receptors to inhibit GABA neurotransmisssion (RodriguezMoreno and Lerma, 1998; Min et al., 1999; Satake et al., 2000). The existence of such a glutamate-to-GABA hierarchy in hypothalamic neuronal circuitries, predicted by the predominance of glutamatergic over GABA synapses in this brain region (Thind and Goldsmith, 1995), has led to the suggestion that an increase in glutamatergic activity is one of the primary changes underlying the activation of LHRH release at puberty (Ojeda and Urbanski, 1994; Bourguignon et al., 1995). In contrast to its kainate receptor-mediated inhibition of GABAergic neurotransmission, glutamate uses both NMDA and kainate receptors to stimulate LHRH release (Urbanski and Ojeda, 1987; Plant et al., 1989; Urbanski and Ojeda, 1990). Although a significant fraction of the kainate receptor-mediated stimulation appears to be exerted directly on LHRH neurons (Eyigor and Jennes, 1997; Eyigor and Jennes, 2000), the NMDA-mediated stimulation may require the intermediacy of other excitatory neurotransmitter systems (Gore et al., 1996) that, endowed with NMDA receptors, are connected synaptically to LHRH neurons. The present results, considered in conjunction with these observations, suggest that, in addition to NMDA and kainate receptors required for the coordination of neuron-to-neuron communication, glutamate uses metabotropic and AMPA receptors to coordinate neuron-to-astrocyte signaling in the developing hypothalamus.

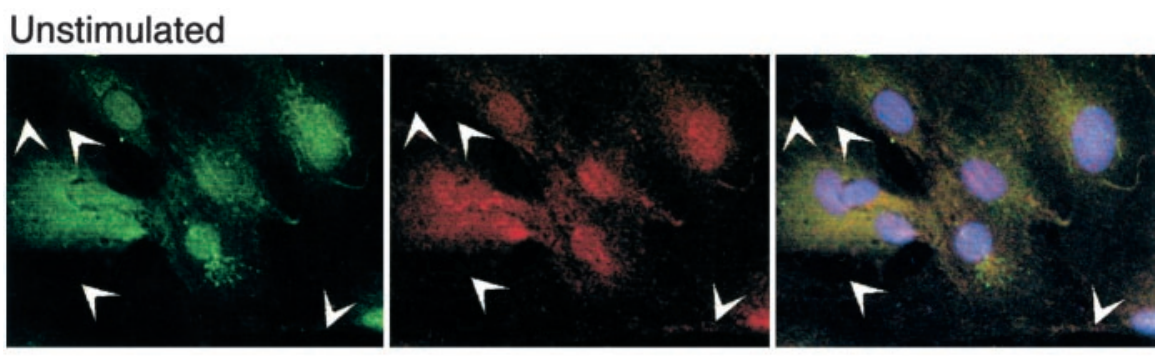

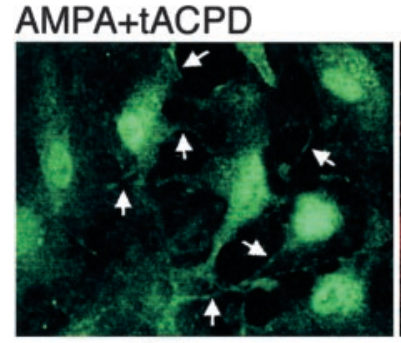

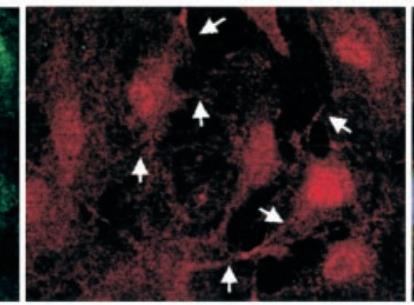

erbB-1

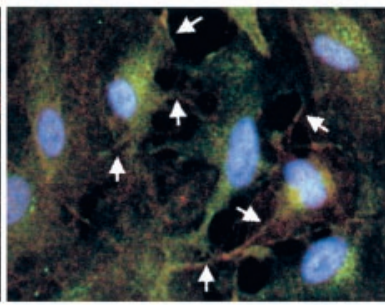

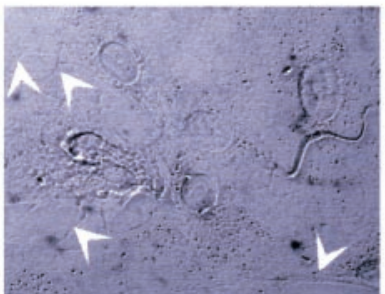

unstimulated

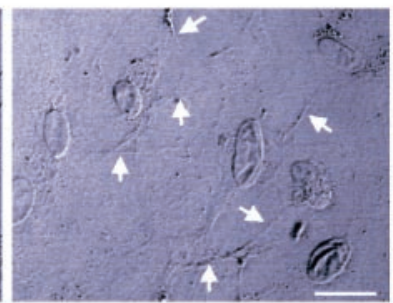

AMPA+tACPD
Figure 8. Coactivation of metabotropic and AMPA receptors enhances the physical proximity of TGF $\alpha$ and its erbB-1 receptor on the cell membrane of cultured astrocytes as assessed by immunohistofluorescence-confocal microscopy. Under basal unstimulated conditions both TGF $\alpha$ and erbB-1 immunoreactivities have a predominant perinuclear and cytoplasmic localization (top rectors) a fraction of both TGF $\alpha$ and erbB-1 immunoreactivities becomes associated to the cell membrane and in close proximity are denoted by arrows). The two bottom panels depict DIC images of the cells shown in the top panels, identifying the cell boundaries (arrowheads point to cell membranes lacking TGF $\alpha$ or erbB-1 immunoreactivity in unstimulated cells; arrows point to cell membranes showing overlapping TGF $\alpha$ and erbB-1 immunoreactive material). Scale bar, $20 \mu \mathrm{m}$.

It was demonstrated previously that the coactivation of AMPA/kainate and metabotropic receptors on astrocytes results in astrocytic glutamate release and that this release requires the production of prostaglandin $\mathrm{E}_{2}$ (Bezzi et al., 1998). In contrast, the independent activation of each of these two receptor subtypes was ineffective. By now showing that coactivation of AMPA and metabotropic receptors results in initiation of erbB-mediated signaling, our results expand these observations and raise the possibility of an involvement of erbB receptors in the process by which neuronal glutamate induces astrocytic $\mathrm{PGE}_{2}$ formation. Astroglial erbB-1 and erbB-4 receptors may contribute to this process because their ligand-mediated activation results in release of $\mathrm{PGE}_{2}$ (Ma et al., 1997, 1999), which then act on LHRH neurons to elicit LHRH secretion. In addition to demonstrating the interdependent involvement of metabotropic and AMPA receptors in glutamate-induced activation of astrocytic erbB signaling, our RNase protection assays and immunoblot analyses identify mGluR5 and GluR2 as the receptor subtypes that are involved. Furthermore, they demonstrate that Homer and PICK1, i.e., the same proteins interacting with these receptors in synapses, are present in hypothalamic astrocytes and that, like in neurons, 


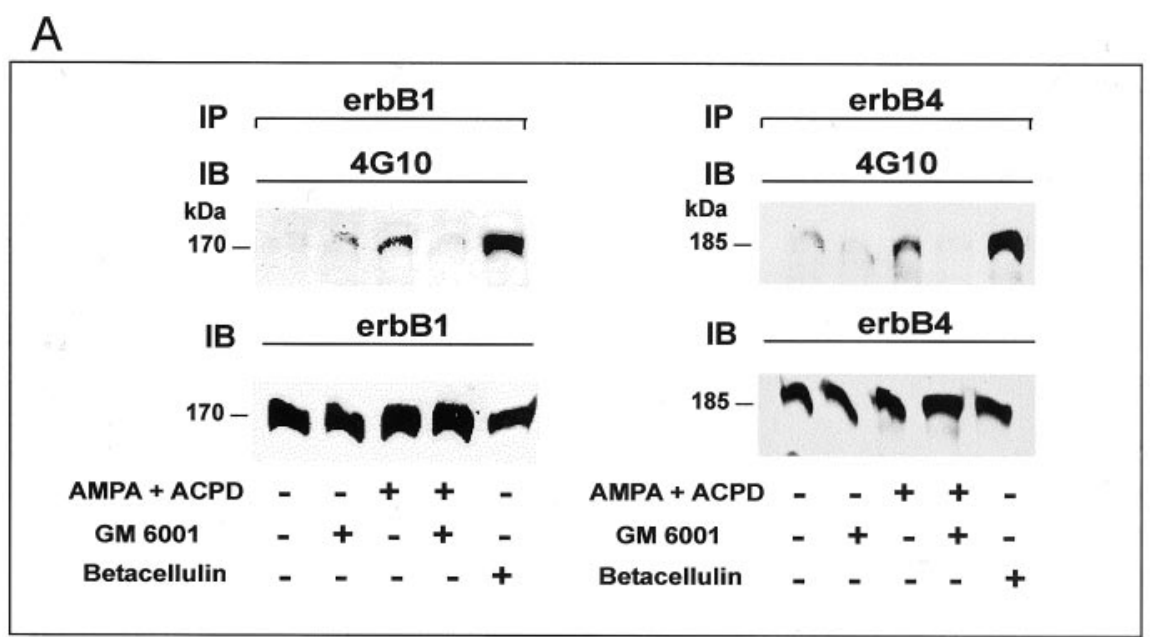

B

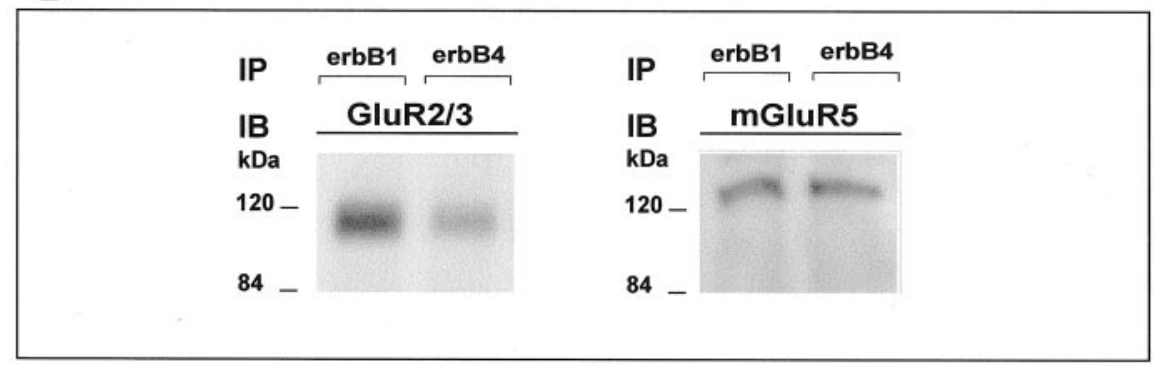

Figure 9. $A$, Concomitant activation of metabotropic and AMPA receptors results in the metalloproteinase-dependent transphosphorylation of both erbB-1 and erbB-4 receptors in hypothalamic astrocytes. Left, ErbB-1 receptors. Astrocytes were cultured in serum-defined medium and were exposed to tACPD/AMPA (at $100 \mu \mathrm{m}$ each) for $15 \mathrm{~min}$. To block metalloproteinase activity, we pretreated some cultures for 30 min with GM 6001 (50 $\mu \mathrm{m}$ ). Proteins were collected after the AMPA/tACPD treatment and immunoprecipitated (IP) with a specific erbB-1 antibody, electrophoresed to size-fractionate the immunoprecipitated species, and immunoblotted $(I B)$ with antibodies to phosphotyrosine (4G10). Then the immunoblot was stripped and reprobed with antibodies to erbB-1 to ensure that equal amounts of erbB-1 protein had been immunoprecipitated and loaded on the gel. Right, ErbB-4 receptors. Astrocytes were treated with tACPD/AMPA (at $100 \mu \mathrm{m}$ each) for $5 \mathrm{~min}$ and exposed to GM 6001 for 30 min before this treatment. After the treatment with AMPA/tACPD the erbB-4 was immunoprecipitated, and the phosphorylated species were detected by immunoblotting with antibody 4G10. Then the immunoblot was stripped and reprobed with antibodies to erbB-4. $B$, Hypothalamic astrocytes were cultured as indicated above; the cellular proteins were collected and immunoprecipitated with specific antibodies to either erbB-1 or erbB-4. After electrophoresis of the immunoprecipitated species the proteins were transferred to nylon membranes and immunoblotted with antibodies to either Glu2/3 or mGluR5.

mGluR5/Homer and Glu2/3/PICK1 are associated physically. The role that these proteins have in astrocytes is unknown, but one of their functions may be to target mGluR5 and GluR2 receptors to sites on the cell membrane near erbB receptors. This possibility is supported by the finding that immunoprecipitation of either erbB-1 or erbB-4 receptors results in the coprecipitation of both GluR2/3 and mGluR5. Consistent with this view, Homer proteins have been shown to target mGluR5 to either dendrites or axons, depending on the type of Homer protein that is involved (Ango et al., 2000), and a very recent report demonstrated that mGluR 5 is associated physically with erbB-1 receptors in cerebrocortical astrocytes (Peavy et al., 2001). Our results show that GluR2/3 and mGluR5 receptors share with erbB-1/erbB-4 a functional relationship that allows astrocytes to transduce glutamatergic inputs into growth factor receptor tyrosine kinasemediated signaling. The existence of such a relationship is demonstrated further by the recent finding that mGluR5mediated activation of extracellular signal-regulated kinase (ERK) phosphorylation in astrocytes requires the intermediacy of erbB-1 (Peavy et al., 2001).

We do not know the mechanism used by mGluR5/GluR2 re- ceptors to promote the recruitment of erbB receptors and their ligands to the cell membrane. One possibility is that Homer, and perhaps PICK1, is involved in this process. There is substantial evidence that Homer acts in neurons to regulate membrane targeting (Ango et al., 2000) and clustering of metabotropic receptors (Xiao et al., 1998), in addition to coupling these receptors to membrane ion channels (Kammermeier et al., 2000) and membrane proteins involved in calcium signaling (Tu et al., 1998). Homer also may mediate interactions of membrane receptors with the actin cytoskeleton (Foa et al., 2001). Similar homologous and heterologous receptor-clustering functions have been ascribed to PICK1 (Xia et al., 1999; Boudin et al., 2000). Our results show the existence of distinct physical associations between mGluR5 and Homer, Glu2/3 and PICK1, and each of these two receptors with erbB-1 and erbB-4, but a much weaker association between Homer or PICK1 with the erbB receptors. Thus Homer and PICK1 may not be involved directly in recruiting astrocytic erbB receptors and their ligands to the cell membrane and bringing them together with the activation of mGluR5/GluR2 receptors. However, their association with Glu2/3 and mGluR5 (which in turn are associated with the erbB receptors) indicates that both are part of the glutamate/ erbB receptor complex that functions in astrocytes to transduce glutamatergic inputs into erbB-mediated signaling.

In addition to linking glutamate receptors to the erbB signaling system in astrocytes, our results show that the mGluR5/ GluR2-dependent transphosphorylation of astrocytic erbB-1 and erbB-4 receptors involves stimulation of a metalloproteinase activity. Metalloproteinase-mediated processing of membrane-bound erbB ligands has been shown to be a likely mechanism underlying the activation of erbB receptors by their respective ligands between cells in contact (Dong et al., 1999; Prenzel et al., 1999). Thus our results suggest that glutamate receptor-induced erbB transphosphorylation requires this proteolytic processing step, which by releasing erbB ligands from their transmembrane precursors would enable them to bind to their cognate receptors. Although the specific metalloproteinase involved in this transactivational process in astrocytes remains to be identified, TACE (ADAM-17) and meltrin $\beta$ (ADAM-19), two members of the ADAM family of metalloproteinases, appear as a likely candidates to mediate the release of mature TGF $\alpha$ and NRG $\beta$ from their respective membrane precursors. Although TACE/ADAM-17 is thought to be involved physiologically in the cleavage of the TGF $\alpha$ precursor in different cell types (Peschon et al., 1998), meltrin $\beta$ has been shown recently to enhance the processing of NRG- $\beta$ s preferentially (Shirakabe et al., 2001). NRG- $\beta$ s stimulate $\mathrm{PGE}_{2}$ release from hypothalamic astrocytes (Ma et al., 1999; Prevot et al., 2003). We now know that TACE is expressed in hypothalamic 
astrocytes, and its biological activity is enhanced by coactivation of metabotropic and AMPA receptors (A. Lomniczi, V. Prevot, A. Costa, A. Cornea, and S. R. Ojeda, unpublished observations). An interesting aspect of this process of regulated ectodomain shedding is the finding that TACE is involved not only in the extracellular processing of erbB receptor ligands but also in the juxtamembrane cleavage of erbB-4 (Rio et al., 2002). In this case the activation of TACE, recently shown to be induced by NRGs themselves (Zhou and Carpenter, 2000), results in both the release of the extracellular domain of erbB-4 and the transient translocation of the native receptor to a detergent-insoluble fraction, where it appears in a hyperphosphorylated state (Zhou and Carpenter, 2000).

Although the physiological importance of ligand-induced shedding of the erbB-4 ectodomain remains to be established, a recent report has shown that the resulting membrane-associated C-terminal fragment of the receptor is cleaved subsequently by a presenilin-dependent $\gamma$-secretase, resulting in the release of the intracellular domain of erbB-4 (Lee et al., 2002). Then this domain is transferred to the cell nucleus, where it may function as a transcription factor (Lee et al., 2002). It thus appears that activation of astrocytic metalloproteinase activity, via stimulation of metabotropic and AMPA receptors, may result in the spectrum of signaling events known to be associated with the stimulation of erbB receptors by their ligands. The use of astrocytes derived from TACE-deficient mice would help to verify the validity of this notion.

In summary, the present results suggest that the glutamatergic neuronal system is linked functionally to astrocytic erbB signaling in the neuroendocrine brain and indicate that this might be an important communication pathway used by glutamatergic neurons to coordinate the activation of stimulatory neuronal and glial inputs to LHRH neurons that are required for the initiation of mammalian puberty.

\section{References}

Abe T, Sugihara H, Nawa H, Shigemoto R, Mizuno N, Nakanishi S (1992) Molecular characterization of a novel metabotropic glutamate receptor mGluR5 coupled to inositol phosphate/ $\mathrm{Ca}^{2+}$ signal transduction. J Biol Chem 267:13361-13368.

Ango F, Pin JP, Tu JC, Xiao B, Worley PF, Bockaert J, Fagni L (2000) Dendritic and axonal targeting of type 5 metabotropic glutamate receptor is regulated by Homer1 proteins and neuronal excitation. J Neurosci 20:8710-8716.

Apostolakis EM, Garai J, Lohmann JE, Clark JH, O’Malley BW (2000) Epidermal growth factor activates reproductive behavior independent of ovarian steroids in female rodents. Mol Endocrinol 14:1086-1098.

Arenander AT, de Vellis J, Herschman HR (1989) Induction of $c$-fos and TIS genes in cultured rat astrocytes by neurotransmitters. J Neurosci Res 24:107-114.

Balázs R, Miller S, Romano C, deVries A, Chun Y, Cotman CW (1997) Metabotropic glutamate receptor mGluR5 in astrocytes: pharmacological properties and agonist regulation. J Neurochem 69:151-163.

Bezzi P, Carmignoto G, Pasti L, Vesce S, Rossi D, Rizzini BL, Pozzan T,
Volterra A (1998) Prostaglandins stimulate calcium-dependent glutamate release in astrocytes. Nature 391:281-285.

Blankenfeld GV, Kettenmann H (1991) Glutamate and GABA receptors in vertebrate glial cells. Mol Neurobiol 5:31-43.

Boudin H, Doan A, Xia J, Shigemoto R, Huganir RL, Worley P, Craig AM (2000) Presynaptic clustering of mGluR7a requires the PICK1 PDZ domain binding site. Neuron 28:485-497.

Boulter J, Hollmann M, O'Shea-Greenfield A, Hartley M, Deneris E, Maron C, Heinemann S (1990) Molecular cloning and functional expression of glutamate receptor subunit genes. Science 249:1033-1037.

Bourguignon J-P, Gérard A, Alvarez Gonzalez ML, Purnelle G, Franchimont $\mathrm{P}$ (1995) The role of excitatory amino acids in triggering the onset of puberty. In: The neurobiology of puberty (Plant TM, Lee PA, eds), pp 129-138. Bristol, UK: Journal of Endocrinology.

Bourguignon J-P, Lebrethon MC, Gérard A, Purnelle G, Vandersmissen E, Parent AS, Yamanaka C (2000) Amino acid neurotransmission and early ontogeny of pulsatile GnRH secretion from the rat hypothalamus. In: The onset of puberty in perspective (Bourguignon J-P, Plant TM, eds), pp 119-129. Amsterdam: Elsevier.

Brakeman PR, Lanahan AA, O'Brien R, Roche K, Barnes CA, Huganir RL, Worley PF (1997) Homer: a protein that selectively binds metabotropic glutamate receptors. Nature 386:284-287.

Bruno V, Sureda FX, Storto M, Casabona G, Caruso A, Knopfel T, Kuhn R, Nicoletti F (1997) The neuroprotective activity of group II metabotropic glutamate receptors requires new protein synthesis and involves a glial-neuronal signaling. J Neurosci 17:1891-1897.

Claypool LE, Kasuya E, Saitoh Y, Marzban F, Terasawa E (2000) N-methyl D,L-aspartate induces the release of luteinizing hormone-releasing hormone in the prepubertal and pubertal female rhesus monkey as measured by in vivo push-pull perfusion in the stalk-median eminence. Endocrinology 141:219-228.

Condorelli DF, Dell'Albani P, Corsaro M, Giuffrida R, Caruso A, Trovato Salinaro A, Spinella F, Nicoletti F, Albanese V, Giuffrida Stella AM (1997) Metabotropic glutamate receptor expression in cultured rat astrocytes and human gliomas. Neurochem Res 22:1127-1133. 
Dissen GA, Romero C, Hirshfield AN, Ojeda SR (2001) Nerve growth factor is required for early follicular development in the mammalian ovary. Endocrinology 142:2078-2086.

Dong H, O’Brien RJ, Fung ET, Lanahan AA, Worley PF, Huganir RL (1997) GRIP: a synaptic PDZ domain-containing protein that interacts with AMPA receptors. Nature 386:279-284.

Dong J, Opresko LK, Dempsey PJ, Lauffenburger DA, Coffey RJ, Wiley HS (1999) Metalloprotease-mediated ligand release regulates autocrine signaling through the epidermal growth factor receptor. Proc Natl Acad Sci USA 96:6235-6240.

Donoso AO, López FJ, Negro-Vilar A (1990) Glutamate receptors of the non- $N$-methyl-D-aspartic acid type mediate the increase in luteinizing hormone-releasing hormone release by excitatory amino acid in vitro. Endocrinology 126:414-420.

Dunbar AJ, Goddard C (2000) Structure-function and biological role of betacellulin. Int J Biochem Cell Biol 32:805-815.

Eyigor O, Jennes L (1997) Expression of glutamate receptor subunit mRNAs in gonadotropin-releasing hormone neurons during the sexual maturation of the female rat. Neuroendocrinology 66:122-129.

Eyigor O, Jennes L (2000) Kainate receptor subunit-positive gonadotropinreleasing hormone neurons express $c$-Fos during the steroid-induced luteinizing hormone surge in the female rat. Endocrinology 141:779-786.

Foa L, Rajan I, Haas K, Wu GY, Brakeman P, Worley P, Cline H (2001) The scaffold protein, Homer $1 \mathrm{~b} / \mathrm{c}$, regulates axon pathfinding in the central nervous system in vivo. Nat Neurosci 4:499-506.

Gallo V, Ghiani CA (2000) Glutamate receptors in glia: new cells, new inputs, and new functions. Trends Pharmacol Sci 21:252-258.

Gore AC, Wu TJ, Rosenberg JJ, Roberts JL (1996) Gonadotropin-releasing hormone and NMDA receptor gene expression and colocalization change during puberty in female rats. J Neurosci 16:5281-5289.

Grasl-Kraupp B, Schausberger E, Hufnagl K, Gerner C, Low-Baselli A, Rossmanith W, Parzelfall W, Schulte-Hermann R (2002) A novel mechanism for mitogenic signaling via pro-transforming growth factor $\alpha$ within hepatocyte nuclei. Hepatology 35:1372-1380.

Hecker KH, Roux KH (1996) High and low annealing temperatures increase both specificity and yield in touchdown and stepdown PCR. Biotechniques 20:478-485.

Hollmann M, O'Shea-Greenfield A, Rogers SW, Heinemann S (1989) Cloning by functional expression of a member of the glutamate receptor family. Nature 342:543-648.

Junier M-P, Hill DF, Costa ME, Felder S, Ojeda SR (1993) Hypothalamic lesions that induce female precocious puberty activate glial expression of the epidermal growth factor receptor gene: differential regulation of alternatively spliced transcripts. J Neurosci 13:703-713.

Kammermeier PJ, Xiao B, Tu JC, Worley PF, Ikeda SR (2000) Homer proteins regulate coupling of group I metabotropic glutamate receptors to $\mathrm{N}$-type calcium and M-type potassium channels. J Neurosci 20:7238-7245.

Lee H-J, Jung K-M, Huang YZ, Bennett LB, Lee JS, Mei L, Kim T-W (2002) Presenilin-dependent $\gamma$-secretase-like intramembrane cleavage of erbB-4. J Biol Chem 277:6318-6323.

Lin SY, Makino K, Xia W, Matin A, Wen Y, Kwong KY, Bourguignon L, Hung MC (2001) Nuclear localization of EGF receptor and its potential new role as a transcription factor. Nat Cell Biol 3:802-808.

Ma YJ, Junier M-P, Costa ME, Ojeda SR (1992) Transforming growth factor $\alpha(\mathrm{TGF} \alpha)$ gene expression in the hypothalamus is developmentally regulated and linked to sexual maturation. Neuron 9:657-670.

Ma YJ, Berg-von der Emde K, Moholt-Siebert M, Hill DF, Ojeda SR (1994) Region-specific regulation of transforming growth factor $\alpha$ (TGF $\alpha$ ) gene expression in astrocytes of the neuroendocrine brain. J Neurosci 14:5644-5651.

Ma YJ, Dissen GA, Rage F, Ojeda SR (1996) RNase protection assay. Methods 10:273-278.

Ma YJ, Berg-von der Emde K, Rage F, Wetsel WC, Ojeda SR (1997) Hypothalamic astrocytes respond to transforming growth factor $\alpha$ with secretion of neuroactive substances that stimulate the release of luteinizing hormone-releasing hormone. Endocrinology 138:19-25.

Ma YJ, Hill DF, Creswick KE, Costa ME, Ojeda SR (1999) Neuregulins signaling via a glial erbB-2/erbB-4 receptor complex contribute to the neuroendocrine control of mammalian sexual development. J Neurosci 19:9913-9927.
Martin DL (1992) Synthesis and release of neuroactive substances by glial cells. Glia 5:81-94.

Martin LJ, Blackstone CD, Huganir RL, Price DL (1992) Cellular localization of a metabotropic glutamate receptor in rat brain. Neuron 9:259-270.

Martínez de la Escalera G, Choi ALH, Weiner RI (1992) Generation and synchronization of gonadotropin-releasing hormone (GnRH) pulses: intrinsic properties of the GT1-1 GnRH neuronal cell line. Proc Natl Acad Sci USA 89:1852-1855.

Masu M, Tanabe Y, Tsuchida K, Shigemoto R, Nakanishi S (1991) Sequence and expression of a metabotropic glutamate receptor. Nature 349:760-765.

McCarthy KD, de Vellis J (1980) Preparation of separate astroglial and oligodendroglial cell cultures from rat cerebral tissue. J Cell Biol 85:890-902.

McNaughton LA, Hunt SP (1992) Regulation of gene expression in astrocytes by excitatory amino acids. Mol Brain Res 16:261-266.

Miller S, Romano C, Cotman CW (1995) Growth factor upregulation of a phosphoinositide-coupled metabotropic glutamate receptor in cortical astrocytes. J Neurosci 15:6103-6109.

Min M-Y, Melyan Z, Kullmann DM (1999) Synaptically released glutamate reduces $\gamma$-aminobutyric acid (GABA)ergic inhibition in the hippocampus via kainate receptors. Proc Natl Acad Sci USA 96:9932-9937.

Nakahara K, Okada M, Nakanishi S (1997) The metabotropic glutamate receptor mGluR5 induces calcium oscillations in cultured astrocytes via protein kinase C phosphorylation. J Neurochem 69:1467-1475.

Nakajima Y, Iwakabe H, Akazawa C, Nawa H, Shigemoto R, Mizuno N, Nakanishi S (1993) Molecular characterization of a novel retinal metabotropic glutamate receptor mGluR6 with a high agonist selectivity for L-2-amino-4-phosphonobutyrate. J Biol Chem 268:11868-11873.

Nishimune A, Isaac JTR, Molnar E, Noel J, Nash SR, Tagaya M, Collingridge GL, Nakanishi S, Henley JM (1998) NSF binding to GluR2 regulates synaptic transmission. Neuron 21:87-97.

Ojeda SR, Terasawa E (2002) Neuroendocrine regulation of puberty. In: Hormones, brain and behavior, Vol 4 (Pfaff D, Arnold A, Etgen A, Fahrbach S, Moss R, Rubin R, eds), pp 589-659. New York: Elsevier.

Ojeda SR, Urbanski HF (1994) Puberty in the rat. In: The physiology of reproduction, 2nd Ed, Vol 2 (Knobil E, Neill JD, eds), pp 363-409. New York: Raven.

Ojeda SR, Ma YJ, Lee BJ, Prevot V (2000) Glia-to-neuron signaling and the neuroendocrine control of female puberty. Recent Prog Horm Res 55:197-224.

Ojeda SR, Prevot V, Heger S (2001) Regulation of puberty. Curr Opin Endocrinol Diabetes 8:154-160.

Parpura V, Basarsky TA, Liu F, Jeftinija K, Jeftinija S, Haydon PG (1994) Glutamate-mediated astrocyte-neuron signaling. Nature 369:744-747.

Peavy RD, Chang MSS, Sanders-Bush E, Conn PJ (2001) Metabotropic glutamate receptor 5-induced phosphorylation of extracellular signalregulated kinase in astrocytes depends on transactivation of the epidermal growth factor receptor. J Neurosci 21:9619-9628.

Peppel K, Baglioni C (1990) A simple and fast method to extract RNA from tissue culture cells. Biotechniques 9:711-713.

Peschon JJ, Slack JL, Reddy P, Stocking KL, Sunnarborg SW, Lee DC, Russell WE, Castner BJ, Johnson RS, Fitzner JN, Boyce RW, Nelson N, Koslosky CJ, Wolfson MF, Rauch CT, Cerretti DP, Paxton RJ, March CJ, Black RA (1998) An essential role for ectodomain shedding in mammalian development. Science 282:1281-1284.

Petch LA, Harris J, Raymond VW, Blasband A, Les DC, Earp HS (1990) A truncated, secreted form of the epidermal growth factor receptor is encoded by an alternatively spliced transcript in normal rat tissue. Mol Cell Biol 10:2973-2982.

Petralia RS, Wang W-X, Niedzielski AS, Wenthold RJ (1996) The metabotropic glutamate receptors, mGluR2 and mGluR3, show unique postsynaptic, presynaptic, and glial localizations. Neuroscience 71:949-976.

Plant TM (1994) Puberty in primates. In: The physiology of reproduction, 2nd Ed, Vol 2 (Knobil E, Neill J, eds), pp 453-485. New York: Raven.

Plant TM, Gay VL, Marshall GR, Arslan M (1989) Puberty in monkeys is triggered by chemical stimulation of the hypothalamus. Proc Natl Acad Sci USA 86:2506-2510.

Prenzel N, Zwick E, Daub H, Leserer M, Abraham R, Wallasch C, Ullrich A (1999) EGF receptor transactivation by G-protein receptors requires metalloproteinase cleavage of pro-HB-EGF. Nature 402:884-888.

Prevot V, Rio C, Cho GJ, Ma YJ, Heger S, Neville CM, Rosenthal NA, Ojeda 
SR, Corfas G (2003) Normal female sexual development requires neuregulin-erbB receptor signaling in hypothalamic astrocytes. J Neurosci 23:230-239.

Püschel AW, O'Connor V, Betz H (1994) The N-ethylmaleimide-sensitive fusion protein (NSF) is preferentially expressed in the nervous system. FEBS Lett 347:55-58.

Rage F, Lee BJ, Ma YJ, Ojeda SR (1997) Estradiol enhances prostaglandin $E_{2}$ receptor gene expression in luteinizing hormone-releasing hormone (LHRH) neurons and facilitates the LHRH response to $\mathrm{PGE}_{2}$ by activating a glia-to-neuron signaling pathway. J Neurosci 17:9145-9156.

Rio C, Buxbaum JD, Peschon JJ, Corfas G (2002) Tumor necrosis factor- $\alpha$ converting enzyme is required for cleavage of erbB-4/HER4. J Biol Chem 275:10379-10387.

Rodriguez-Moreno A, Lerma J (1998) Kainate receptor modulation of GABA release involves a metabotropic function. Neuron 20:1211-1218.

Satake S, Saitow F, Yamada J, Konishi S (2000) Synaptic activation of AMPA receptors inhibits GABA release from cerebellar interneurons. Nat Neurosci 3:551-558.

Shirakabe K, Wakatsuki S, Kurisaki T, Fujisawa-Sehara A (2001) Roles of meltrin $\beta /$ ADAM 19 in the processing of neuregulin. J Biol Chem 276:9352-9358.

Song I, Kamboj S, Xia J, Dong H, Liao D, Huganir RL (1998) Interaction of the $\mathrm{N}$-ethylmaleimide-sensitive factor with AMPA receptors. Neuron 21:393-400.

Staudinger J, Zhou J, Burgess R, Elledge SJ, Olson EN (1995) PICK1: a perinuclear binding protein and substrate for protein kinase $\mathrm{C}$ isolated by the yeast two-hybrid system. J Cell Biol 128:263-271.

Tanabe Y, Masu M, Ishii T, Shigemoto R, Nakanishi S (1992) A family of metabotropic glutamate receptors. Neuron 8:169-179.

Terasawa E (1999) Hypothalamic control of the onset of puberty. Curr Opin Endocrinol Diabetes 6:44-49.
Testa CM, Standaert DG, Young AB, Penny Jr JB (1994) Metabotropic glutamate receptor mRNA expression in the basal ganglia of the rat. J Neurosci 14:3005-3018.

Thind KK, Goldsmith PC (1995) Glutamate and GABAergic neurointeractions in the monkey hypothalamus: a quantitative immunomorphological study. Neuroendocrinology 61:471-485.

Tu JC, Xiao B, Yuan JP, Lanahan AA, Leoffert K, Li M, Linden DJ, Worley PF (1998) Homer binds a novel proline-rich motif and links group 1 metabotropic glutamate receptors with $\mathrm{IP}_{3}$ receptors. Neuron 21:717-726

Urbanski HF, Ojeda SR (1987) Activation of luteinizing hormone-releasing hormone release advances the onset of female puberty. Neuroendocrinology 46:273-276.

Urbanski HF, Ojeda SR (1990) A role for N-methyl-D-aspartate (NMDA) receptors in the control of $\mathrm{LH}$ secretion and initiation of female puberty. Endocrinology 126:1774-1776.

van den Pol AN, Trombley PQ (1993) Glutamate neurons in hypothalamus regulate excitatory transmission. J Neurosci 13:2829-2836.

van den Pol AN, Romano C, Ghosh P (1995) Metabotropic glutamate receptor mGluR5 subcellular distribution and developmental expression in hypothalamus. J Comp Neurol 362:134-150.

Xia J, Zhang X, Staudinger J, Huganir RL (1999) Clustering of AMPA receptors by the synaptic PDZ domain-containing protein PICK1. Neuron 22:179-187.

Xiao B, Tu JC, Petralia RS, Yuan JP, Doan A, Breder CD, Ruggiero A, Lanahan AA, Wenthold RJ, Worley PF (1998) Homer regulates the association of group 1 metabotropic glutamate receptors with multivalent complexes of Homer-related, synaptic proteins. Neuron 21:707-716.

Zhou W, Carpenter G (2000) Heregulin-dependent trafficking and cleavage of erbB-4. J Biol Chem 275:34737-34743. 